\title{
Modulation of Hypothalamic-Pituitary-Adrenal Function by Transgenic Expression of Interleukin-6 in the CNS of Mice
}

\author{
Jacob Raber, Ross D. O'Shea, Floyd E. Bloom, and lain L. Campbell \\ Department of Neuropharmacology, The Scripps Research Institute, La Jolla, California 92037
}

Interleukin-6 (IL-6) and IL-6 receptor mRNA and protein have been reported in different brain regions under normal and pathophysiological conditions. Although much is known about the hypothalamic-pituitary-adrenal (HPA) axis stimulation after acute administration, less is known about the chronic effects of IL- 6 on the function of the HPA axis. In the present study, we examined the function of the HPA axis in transgenic mice in which constitutive expression of IL-6 under the control of the glial fibrillary acidic protein (GFAP) promoter was targeted to astrocytes in the CNS. GFAP-IL6 mice heterozygous or homozygous for the IL-6 transgene had normal basal plasma corticosterone levels but, after restraint stress, showed abnormally increased levels in a gene dose-dependent manner. The increased plasma corticosterone levels in the IL-6 transgenic mice were associated with increased adrenal corticosterone content and hyperplasia of both adrenal cortex and medulla. Notably, plasma adrenocorticotrophic hormone (ACTH) levels and pituitary ACTH content were either not changed or decreased in these mice, whereas plasma arginine vasopressin (AVP) was increased, supporting a role for AVP in response to acute immobilization stress. The reduced ACTH response together with the adrenal hyperplasia in the IL-6 transgenic mice suggests direct activation at the level of the adrenal gland that may be directly activated by AVP or sensitized to ACTH. A similar mechanism may play a role in the blunted ACTH response and elevated corticosterone levels under pathophysiological conditions observed in humans with high brain levels of IL-6.

Key words: interleukin-6; hypothalamus; pituitary; adrenal gland; ACTH; corticosterone; HPA axis; transgenic
Interleukin-6 (IL-6) is a multifunctional inflammatory cytokine (Taga and Kishimoto, 1992). IL-6 mRNA has been detected in the normal rat brain (Schöbitz et al., 1993; De Kloet et al., 1994; Gadient and Otten, 1994, 1995), and IL-6 and IL-6 receptor (IL-6R) mRNAs have been colocalized in several rat brain regions (Schöbitz et al., 1993; De Kloet et al., 1994), including white matter areas consisting only of fibers and glial cells (Schöbitz et al., 1993). In contrast to the rat, no IL-6 mRNA was detectable in the brain of normal mice (Campbell et al., 1993, 1994). Increased IL-6 levels in the mouse brain are implicated in the development of neuropathological alterations (Campbell et al., 1994).

Elevated IL-6 levels have been detected in brain, cerebrospinal fluid, and/or plasma of patients with various disorders, including infection of the CNS (Frei et al., 1988; Matsuzono et al., 1995) or immunodeficiency diseases such as human immunodeficiency virus (HIV)-1 infection (Biglino et al., 1995), Alzheimer's disease (Bauer, 1994; Huell et al., 1995), multiple sclerosis (Shimada et al., 1993; Perez et al., 1995), acute cerebral ischemia (Fassbender et al., 1994), trauma (Amado et al., 1995), depression (Maes et al., 1993, 1995), and schizophrenia (Ganguli et al., 1993). Ultrastructural studies on human neurons in tissue culture have demonstrated that IL-6 treatment induced large cytoplasmic vacuoles in

Received July 30, 1997; revised Sept. 29, 1997; accepted Oct. 1, 1997.

This work was supported by National Institutes of Health Grants MH47680 (F.E.B.) and MH50426 (I.L.C.), by the National Health and Medical Research Council (Australia) C. J. Martin Fellowship (R.D.O.), and by the SchumacherKramer Foundation (J.R.). This is manuscript 10670-NP from the Scripps Research Institute. We are grateful to Elena F. Battenberg for help with the histological analysis of the adrenal gland.

Correspondence should be addressed to Dr. Jacob Raber, The Gladstone Molecular Neurobiology Program and Department of Neurology, University of California, P.O. Box 419100, San Francisco, CA 94141-9100.

Copyright (C) 1997 Society for Neuroscience $0270-6474 / 97 / 179473-08 \$ 05.00 / 0$ neural cells with neuronal morphology (Yeung et al., 1995). In addition, human brain cell aggregates, astrocytes, and astrocytoma cells can be induced to secrete IL-6 (Bauer, 1994; Gitter et al., 1995; Yeung et al., 1995).

IL-6 has been reported to stimulate the hypothalamic-pituitary-adrenal (HPA) axis (Harbuz et al., 1992; Hu et al., 1993, Mastorakos et al., 1993, 1994; Spath-Schwalbe et al., 1994) and plasma arginine vasopressin (AVP) secretion (Mastorakos et al., 1994). The HPA axis in humans chronically treated with IL-6 (Mastorakos et al., 1993; Spath-Schwalbe et al., 1994) and in patients with various disorders associated with elevated IL-6 levels in the brain and cerebrospinal fluid, including Alzheimer's disease, multiple sclerosis, and depression (Gold et al., 1995; Hatzinger et al., 1995), exhibits a blunting of adrenocorticotrophic hormone (ACTH) but not cortisol responses, and the diminished ACTH responses resemble those during chronic stress (Aguilera, 1994). Most studies have described HPA axis stimulation after acute IL-6 administration; little is known about the chronic effects of IL- 6 on the modulation of the HPA axis. Recently, a transgenic model was established in which constitutive CNS expression of IL-6, under the control of the glial fibrillary acidic protein (GFAP) gene promoter, produced progressive neurological disease with a spectrum of neuropathological manifestations, including neurodegeneration, gliosis (Campbell et al., 1993; Chiang et al., 1994; Heyser et al., 1997), and breakdown of the blood-brain barrier (Brett et al., 1995). This model provides an opportunity to investigate the chronic effects of IL- 6 on the CNS.

The objective of the present study was to determine whether transgenic expression of IL-6 in the CNS of mice can influence the HPA axis under basal conditions or after activation of the axis by stress. 


\section{MATERIALS AND METHODS}

Animals. Transgenic mice expressing IL-6 under the control of the GFAP promoter were generated as described previously (Campbell et al., 1993). IL-6 transgenic mice of the G167 line (3-6 months of age) and their nontransgenic littermates were used in the current experiments. Mice were housed at no more than four per cage under conditions of constant temperature $\left(18^{\circ} \mathrm{C}\right)$, regular light cycle, and access to water and food ad libitum. To avoid circadian variation, we tested or killed the mice between 10:00 and 12:00 A.M.

Dissection of hypothalami and amygdala. Mice were killed by decapitation, and the brain was rapidly removed. A brain slicer (San Diego Instruments, San Diego, CA) was used to obtain a 1.5-mm-thick corona slice, including structures $-0.7 \mathrm{~mm}$ caudal to bregma, according to Slotnick and Leonard (1975). Subsequently the hypothalamus and amygdala were dissected out as described previously (Raber et al., 1997). The dissected tissues were frozen on dry ice and stored at $-70^{\circ} \mathrm{C}$ until assay for AVP or corticotropin-releasing factor (CRF) immunoreactivity ( $n=$ 10 mice per group).

Immobilization stress. In experiments designed to compare basal plasma corticosterone levels between IL-6 transgenic mice and wild-type littermates, mice were anesthetized with metofane for $2 \mathrm{~min}$ and subsequently tail-bled using heparinized capillary tubes (Natelson; Baxter, McGaw Park, IL) into microf uge tubes that were kept on ice $(n=5-10)$. These were considered baseline values. The mice used to determine basal plasma ACTH levels were anesthetized, killed by decapitation, and bled into EDTA-containing tubes (Microtainer; Becton Dickinson, Rutherford, $\mathrm{NJ})(n=5-10)$.

Restraint stress was used to study whether any IL-6 effect on plasma ACTH and corticosterone was gene dose-dependent. Transgenic mice or controls were placed in a restrainer for 5 or $20 \mathrm{~min}$, anesthetized (as above), killed by decapitation, and bled into EDTA-containing tubes. After centrifugation at $10,000 \times g$ for $10 \mathrm{~min}$ at $4^{\circ} \mathrm{C}$, supernatants were stored at $-70^{\circ} \mathrm{C}$ until assay for corticosterone or ACTH $(n=8-10)$. To determine the effect of IL-6 on the pituitary ACTH content and the hypothalamic and amygdaloid AVP and CRF contents, we anesthetized the mice with metofane, and the pituitaries were dissected out and placed on dry ice until extraction and assay for ACTH, AVP, or CRF ( $n=10$ mice per group). To assess the effects of IL- 6 on adrenal corticosterone content, we stressed the mice for $5 \mathrm{~min}$ and anesthetized them (as above), and the adrenals were dissected out and placed on dry ice until extraction for corticosterone determination.

Hypothalamic and amygdaloid AVP and CRF and pituitary ACTH extraction. The hypothalamic and amygdaloid AVP and CRF and the pituitary ACTH were extracted by addition of $500 \mu \mathrm{l}$ of $2 \mathrm{~N}$ acetic acid. Samples were then boiled for $10 \mathrm{~min}$, cooled on ice, and sonicated twice for $3 \mathrm{sec}$ with a Vir Sonic 50 sonicator (The Virtis Company, Gardiner, NY). The sonicates were centrifuged at $10,000 \times g$ for $10 \mathrm{~min}$, and after removal of an aliquot for protein determination (Micro BCA protein assay reagent kit; Pierce, Rockford, IL), samples containing $450 \mu$ l were lyophilized overnight (Freeze mobile 5SL; The Virtis Company). The lyophilized samples were resuspended in $450 \mu$ l of radioimmunoassay (RIA) buffer (see below) and stored at $-70^{\circ} \mathrm{C}$ until assay for AVP, CRF, or ACTH immunoreactivity.

Adrenal corticosterone extraction. For adrenal corticosterone extraction, the adrenals were homogenized in $5 \mathrm{ml}$ of $0.1 \mathrm{M} \mathrm{PBS}, \mathrm{pH} 7.4$, using a Polytron (The Virtis Company). After adding $5 \mathrm{ml}$ of iso-octane and 5 $\mathrm{ml}$ of ethylacetate, the samples were vortexed for 5-8 $\mathrm{min}$ using a multitube vortexer and centrifuged at $4000 \mathrm{rpm}$ for $5 \mathrm{~min}$ in an Omnifuge RT, and the upper organic phase was extracted according to the protocol of Mellon et al. (1980), as modified by Akwa et al. (1993). The extraction procedure was repeated twice, and the organic phase was evaporated under a stream of nitrogen gas at $60^{\circ} \mathrm{C}$. The pellets were resuspended in $400 \mu \mathrm{l}$ of methanol and $600 \mu \mathrm{l}$ of steroid diluent (ICN Biomedicals, Cleveland, $\mathrm{OH}$ ) and stored in the dark at $4^{\circ} \mathrm{C}$ until assay for corticosterone.

Adrenal histology. To investigate the effect of IL-6 on adrenal structure, we examined the histological appearance of adrenal glands from IL-6 transgenic mice. The adrenal glands were formalin-fixed and paraffinembedded. Sections $(5 \mu \mathrm{m})$ were stained with hemotoxylin and eosin, and bright-field photographs were taken on a Zeiss Axiophot microscope.

Plasma AVP extraction. To investigate the effect of IL-6 on plasma AVP levels, we used 5 min restraint-stressed IL-6 transgenic mice anesthetized as described above and bled into EDTA-containing tubes (Microtainer; Becton Dickinson). AVP was extracted from the plasma after addition of chilled ethanol by vortexing for $2 \mathrm{~min}$ at room temperature using a multitube vortexer, centrifuging at $2000 \times g$ at $4^{\circ} \mathrm{C}$ for $15 \mathrm{~min}$, decanting the supernatant into clean tubes, and evaporating the supernatants to dryness at $37^{\circ} \mathrm{C}$ under a stream of nitrogen gas using a Reacti-Vap III.

$A V P$ and CRF RIA. The concentrations of AVP and CRF were measured in polypropylene tubes by RIA according to the method of Skowsky et al. (1974), modified by Weitzman et al. (1978), using a specific rabbit polyclonal antibody against AVP (gift from Dr. A. Burlet, Bordeaux, France) or CRF (gift from Dr. W. Vale, The Salk Institute, La Jolla, CA) and synthetic vasopressin (gift from Dr. P. Plotsky, Atlanta, GA) or synthetic CRF (gift from Dr. W. Vale), as reported previously (Raber et al., 1994, 1995). ${ }^{125}$ I-AVP was obtained from Amersham (Arlington Heights, IL), and ${ }^{125} \mathrm{I}-\mathrm{CRF}$ was from DuPont NEN (Boston, MA). Pretitered goat anti-rabbit and normal rabbit serum were obtained from Peninsula Laboratories (Belmont, CA). All standards were measured in triplicate and the samples in duplicate. The lower detection limit of the assay was $3 \mathrm{pg} /$ tube (100 $\mu \mathrm{l}$ of sample volume). The intra- and interassay coefficients of variation were 3 and $10 \%$ for the AVP RIA and 4 and $11 \%$ for the CRF RIA, respectively.

$A C T H$ and corticosterone RIA. Plasma ACTH was determined using a ACTH RIA kit (Nichols Institute, Capistrano, CA). The intra- and interassay coefficients of variation were 3 and $7 \%$, respectively. Plasma corticosterone was determined using a corticosterone RIA kit for rats and mice (ICN Biomedicals). The intra- and interassay coefficients of variation were both $7 \%$.

$R N A$ isolation. Hemibrains were removed and snap-frozen in liquid nitrogen. Poly $\left(\mathrm{A}^{+}\right)$-enriched RNA was isolated, according to the method of Badley et al. (1988). Briefly, hemibrains were placed in $10 \mathrm{ml}$ of lysis buffer $\left(0.2 \mathrm{M} \mathrm{NaCl}, 0.2 \mathrm{M}\right.$ Tris-HCl, pH 7.5, $1.5 \mathrm{mM} \mathrm{MgCl}_{2}, 2 \% \mathrm{SDS}$, and $200 \mu \mathrm{g} / \mathrm{ml}$ proteinase $\mathrm{K}$ ) and immediately homogenized. After incubation for $60 \mathrm{~min}$ at $45^{\circ} \mathrm{C}$, the $\mathrm{NaCl}$ concentration of the lysate was adjusted to $0.5 \mathrm{M}$, and the lysate was mixed with $40 \mathrm{mg}$ of oligo-dT cellulose (Invitrogen, San Diego, CA) that had been pre-equilibrated in binding buffer $(0.5 \mathrm{M} \mathrm{NaCl}$ and $0.01 \mathrm{M}$ Tris- $\mathrm{HCl}, \mathrm{pH} 7.5)$. After incubation of the mixture for $60 \mathrm{~min}$ at $25^{\circ} \mathrm{C}$ with gentle rocking and a subsequent wash with binding buffer, poly $\left(\mathrm{A}^{+}\right)$RNA was eluted from the oligo-dT cellulose with $0.5 \mathrm{ml}$ of elution buffer containing $0.01 \mathrm{M}$ Tris-HCl, pH 7.5, precipitated in ethanol, dried, and resuspended in $25 \mu \mathrm{l}$ of elution buffer. The RNA concentration was determined by UV spectroscopy at $260 \mathrm{~nm}$.

Northern blot analysis. For Northern blot analysis, $5 \mu \mathrm{g}$ of $\operatorname{poly}\left(\mathrm{A}^{+}\right)$ RNA was denatured, electrophoresed in a $1 \%$ agarose and $2.2 \mathrm{M}$ formaldehyde gel, and transferred to a nylon membrane. The membrane was prehybridized in hybridization buffer, containing $6 \times$ saline-sodium phosphate-EDTA (SSPE) buffer, $\mathrm{pH} 7.6$, 50\% formamide, $5 \times$ Denhardt's solution, $0.2 \% \mathrm{SDS}$, and $10 \mathrm{mg} / \mathrm{ml}$ Salmon sperm DNA, for $1 \mathrm{hr}$ at $45^{\circ} \mathrm{C}$ and hybridized overnight at $45^{\circ} \mathrm{C}$ with ${ }^{32} \mathrm{P}$-labeled cDNA probes. The AVP cDNA probe from rat was a gift from Dr. P. P. Sanna, La Jolla, CA. To correct for differences in loading, we also probed blots for $\beta$-actin. After hybridization and washing, blots were exposed to x-ray film for $16 \mathrm{hr}$ (for AVP) or $4 \mathrm{hr}$ (for $\beta$-actin) with intensifying screens at $-70^{\circ} \mathrm{C}$. The intensity of the AVP and $\beta$-actin bands was quantified using National Institutes of Health Image 1.57.

Statistical analysis. Data, expressed as mean \pm SEM, were analyzed statistically using ANOVA followed by a Tukey test when appropriate. A $p$ value of $<0.05$ was considered significant.

\section{RESULTS}

\section{Plasma corticosterone levels in GFAP-IL-6 mice}

Plasma corticosterone levels were analyzed in IL-6 transgenic mice to determine whether chronic transgene expression of IL-6 could modulate the HPA axis. As shown in Figure $1 A$, basal corticosterone levels were not significantly altered in heterozygous $(+/ T g)$ or homozygous $(T g / T g)$ IL-6 transgenic mice, compared with nontransgenic littermate controls.

To determine whether there were adaptation and sensitization of the HPA axis in the IL-6 transgenic mice, we assessed the effect of restraint stress on plasma corticosterone levels in 8-weekold mice. After 5 min of restraint stress, there was an increase in plasma corticosterone levels in nontransgenic mice, which was further increased after $20 \mathrm{~min}$ of restraint stress (Fig. 1A). After 5 min of restraint stress, the plasma corticosterone level in ho- 
A

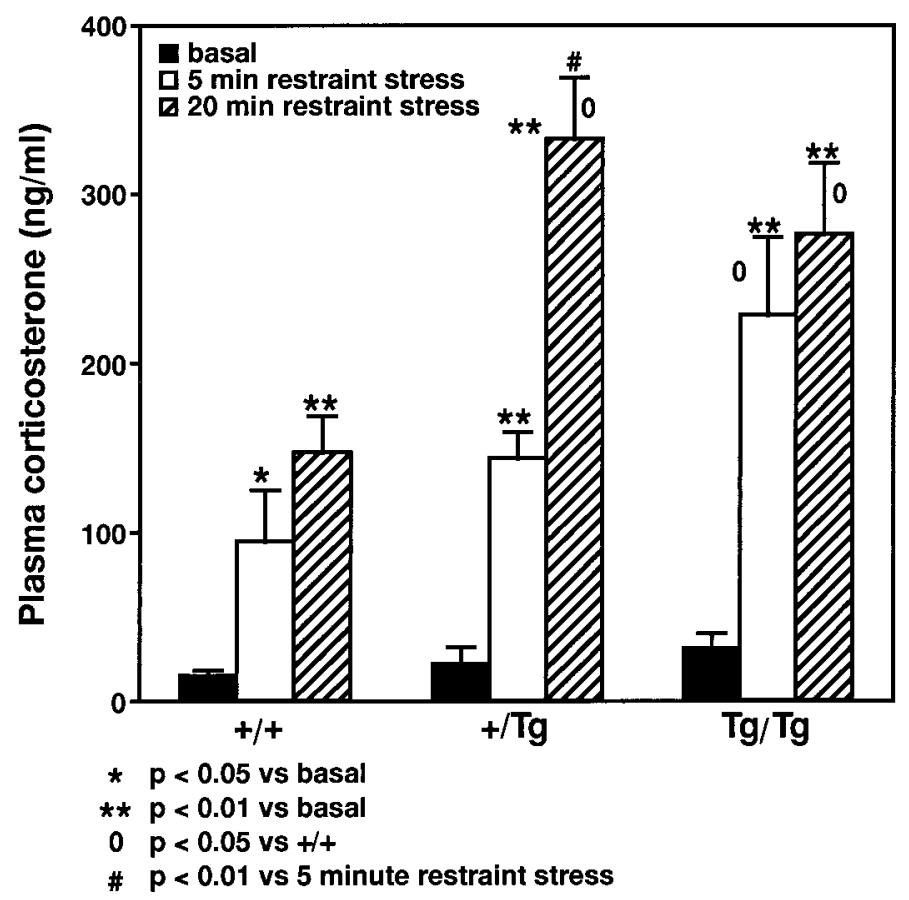

B

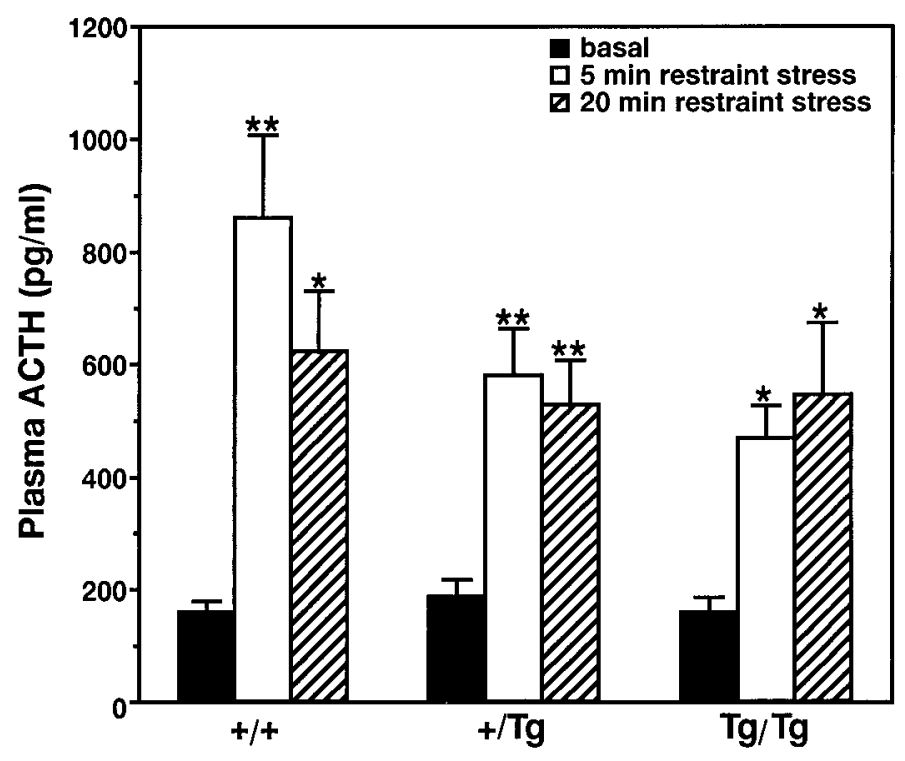

Figure 1. Basal and restraint stress-induced plasma corticosterone $(A)$ and $\mathrm{ACTH}(B)$ levels in wild-type $(+/+)$ mice and in heterozygous $[+/$ transgenic $(T g)]$ and homozygous $(T g / T g) ~ I L-6$ transgenic mice. The mice were anesthetized and bled to determine basal levels or placed in a restrainer for 5 or $20 \mathrm{~min}$, anesthetized, and bled to determine stress-induced levels ( $n=5-10$ mice per group).

mozygous, but not in heterozygous, IL-6 transgenic mice was significantly higher than in the controls. After 20 min of restraint stress, the plasma corticosterone levels were significantly higher in both heterozygous and homozygous IL- 6 transgenic mice than in the controls. The increased plasma corticosterone levels in IL-6 transgenic mice after stress was observed in young as well as in older animals ( 6 weeks to 7 months of age) but was not age dependent (data not shown).

\section{Plasma ACTH levels and pituitary ACTH content in GFAP-IL-6 mice}

Plasma ACTH levels and pituitary ACTH content were analyzed to determine the role of $\mathrm{ACTH}$ in the restraint stress-induced plasma corticosterone elevations. As shown in Figure $1 B$, there was no significant difference in the basal plasma ACTH levels between the IL- 6 transgenic mice and the controls. After 5 or 20 min of restraint stress, plasma ACTH levels increased in both nontransgenic and IL-6 transgenic mice. However, the rise in plasma ACTH levels in IL-6 transgenic mice was far less than that seen in control mice and was disproportional to the increases in corticosterone levels. In fact, compared with the controls after 5 min of restraint stress, the plasma ACTH levels were reduced in the IL-6 transgenic mice in a gene dose-dependent manner (Fig. 1B).

Release of pro-opiomelanocortin (POMC)-derived peptides is involved in HPA axis activation. In addition to ACTH, we also assessed the plasma levels of the POMC-derived $\beta$-endorphin in the IL- 6 transgenic mice. After $20 \mathrm{~min}$ of restraint stress, there was no difference in plasma $\beta$-endorphin levels between IL-6 transgenic and control mice (data not shown). Next we deter- mined whether the reduced ACTH levels might reflect alterations in the pituitary ACTH content. Pituitary ACTH was slightly lower (not statistically significant) in the heterozygous IL-6 transgenic mice than in the controls and was significantly lower in the homozygous IL-6 transgenic mice than in the controls (Fig. 2).

\section{ACTH secretagogues and plasma AVP levels in IL-6 transgenic mice}

Plasma AVP levels were analyzed in IL-6 transgenic mice to determine whether AVP could play a direct role in the activation of the adrenal gland. The plasma AVP levels after 5 min of restraint stress were highly elevated in heterozygous IL-6 transgenic mice $[123.9 \pm 47.3 \mathrm{pg} / \mathrm{ml}(n=6)]$ versus control mice $[15.9 \pm 3.6 \mathrm{pg} / \mathrm{ml}(n=4)]$.

We next determined the tissue levels of the ACTH secretagogues AVP and CRF in the hypothalamus and amygdala. The hypothalamic and amygdaloid AVP and CRF contents in the heterozygous and homozygous IL-6 transgenic mice were not significantly different from that of nontransgenic littermates (Table 1). Cerebral AVP mRNA levels were determined in the IL-6 transgenic and control mice. As shown in Table 2, there was no significant difference in the cerebral AVP mRNA content of heterozygous and homozygous IL- 6 transgenic mice compared with that of nontransgenic controls.

To determine whether hypothalamic release of CRF and AVP might mediate the increased plasma corticosterone levels, we compared the release of these factors from superfused hypothalamic slices from IL-6 transgenic and control mice, but no significant difference in basal or acetylcholine-induced release of either CRF or AVP was observed (data not shown). 


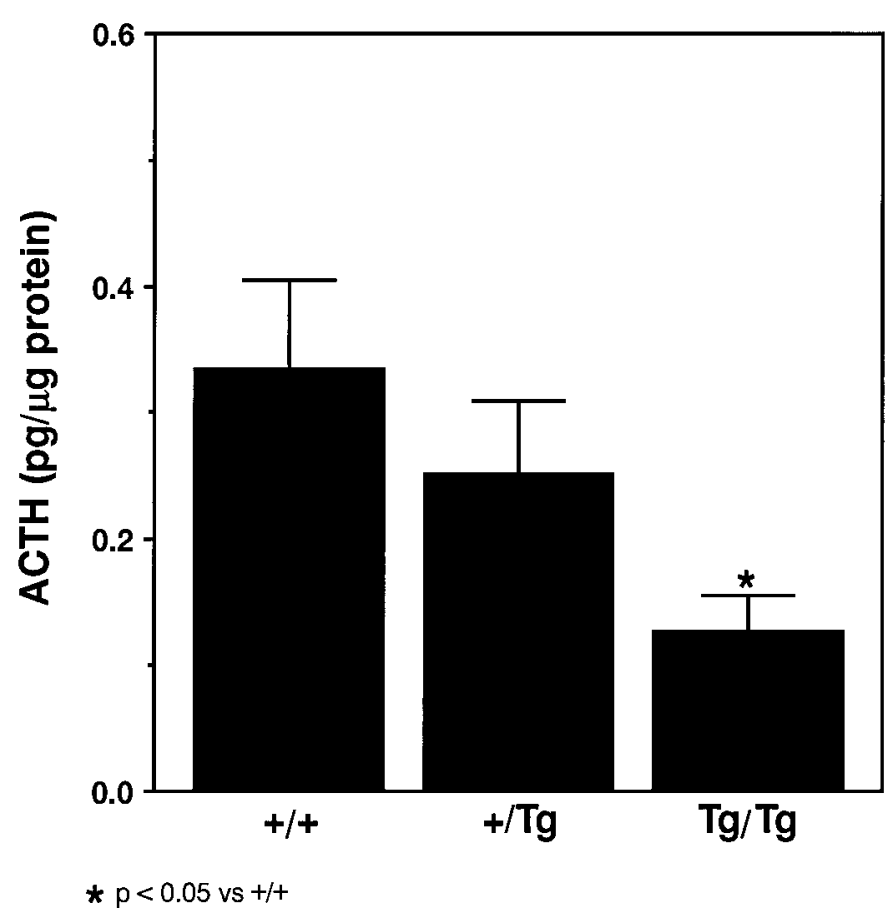

Figure 2. Pituitary ACTH content in wild-type $(+/+)$ mice and in heterozygous $(+/ T g)$ and homozygous $(T g / T g)$ IL-6 transgenic mice. The pituitary ACTH content was determined as described in Materials and Methods ( $n=9-10$ mice per group).

\section{Adrenal corticosterone and pituitary AVP content in IL-6 transgenic mice}

As shown in Table 3, after 5 min of restraint stress, there was a significant increase in adrenal corticosterone content in heterozygous IL-6 transgenic mice compared with nontransgenic littermate controls, which is in agreement with the increased plasma corticosterone after restraint stress in the IL-6 transgenic mice. Pituitary AVP levels were examined because increased plasma corticosterone levels might relate to alterations in pituitary AVP content. The increased adrenal corticosterone content in the heterozygous IL-6 transgenic mice was paralleled by a trend toward a higher pituitary AVP content, but this change did not reach statistical significance.

\section{Adrenal histology in IL-6 transgenic mice}

The changes in adrenal corticosterone content were paralleled by a number of histological alterations (Fig. 3). The adrenal cortex and medulla of the IL- 6 transgenic mice, which showed increased adrenal corticosterone content, were hyperplastic. The cells did not look tumorous, but the number of cells was increased. The cortex of the IL- 6 transgenic mouse specimen was approximately double the thickness of the cortex of the wild-type control specimen, and there were both an increased number of cells (in the glomerulosa layer) and a hypertrophic response with nuclei spaced farther apart (in the layers reticularis and fasciculata).

\section{IL-6 transgene expression}

IL-6 transgene expression in the pituitary and adrenal gland was examined by RNase protection assay because increased IL-6 levels in these organs could contribute to the HPA axis activation. However, no IL-6 mRNA expression was detected in either the pituitary or adrenal gland (data not shown). To determine whether IL-6 in the plasma could directly activate the adrenal gland, possibly in synergism with plasma ACTH, we assessed the levels of IL- 6 in the plasma of transgenic IL- 6 mice by bioassay and ELISA. There was no detectable IL- 6 present in the plasma of IL-6 transgenic mice or of controls (data not shown).

\section{DISCUSSION}

The present results demonstrate that chronic cerebral expression of IL-6 results in activation of the HPA axis via a novel mechanism primarily effected at the adrenal gland. After restraint stress, the plasma corticosterone responses were greater in the heterozygous and homozygous IL- 6 transgenic mice in a gene dose-dependent manner, but their plasma and pituitary ACTH contents were either not changed or reduced compared with the levels in controls. However, the adrenal corticosterone content and plasma AVP levels were elevated in stressed IL-6 transgenic mice, in parallel with hyperplasia of both the adrenal cortex and medulla. The reduced ACTH response together with the adrenal hyperplasia in the IL-6 transgenic mice suggests direct activation at the level of the adrenal gland, which may be directly activated by AVP and/or sensitized to ACTH.

Most studies on the central effects of IL-6 have been done in the rat, and little is known about its effects in the mouse. There may be an important species difference between central IL-6 effects in rat and mouse, because IL-6 mRNA has been detected in normal rat brain (Schöbitz et al., 1993; De Kloet et al., 1994; Gadient and Otten, 1994, 1995) but not in mouse brain (Campbell et al., 1993). In rat, the site of action for the IL-6 stimulation of the HPA axis seems to be at the level of not only the hypothalamus (Loxley et al., 1991, 1993; Lyson et al., 1991; Navarra et al., 1991; Lyson and McCann, 1992; Spinedi et al., 1992; Raber et al., 1994; Yasin et al., 1994; Kageyama et al., 1995) but also the pituitary (Bateman et al., 1989; Stephanou et al., 1992; Muramami et al., 1993; Sarlis et al., 1993) and adrenal gland (Muramami et al., 1993, Gonzalez-Hernandez et al., 1994). IL-6 mRNA has been reported in the rat anterior pituitary (Vankelecom et al., 1989; Spangelo et al., 1990, 1994), in which it is increased in conditions associated with chronic stimulation of the HPA axis (Stephanou et al., 1992), and is under the control of glucocorticoid feedback (Sarlis et al., 1993). In addition, IL-6 induces ACTH release both in vivo and in vitro (Bateman et al., 1989; Spangelo et al., 1994). Furthermore, lipopolysaccharide (LPS) is able to activate the pituitary-adrenal axis in rats with paraventricular nucleus (PVN) lesions (Elenkov et al., 1992) and to increase serum IL-6 levels and IL-6 mRNA in peripheral organs (Schöbitz et al., 1993), supporting a direct effect on the pituitary or extrapituitary nonPVN pathways of HPA axis activation (Elenkov et al., 1992).

Physical or psychological stress increases plasma IL-6 in rats with kinetics that resembles the increase in plasma corticosterone; these changes are attenuated by adrenalectomy, and IL-6 induces acute-phase proteins with glucocorticoids from the adrenal gland (Zhou et al., 1993). IL-6 mRNA was also reported in 17 $\alpha$-hydroxylase-immunoreactive steroid cells in the inner zone of the adrenal cortex and in CD-6-positive macrophages in the zona reticularis in humans (Gonzalez-Hernandez et al., 1994).

However, the inability to detect IL-6 mRNA in the pituitary and adrenal gland or IL- 6 in the plasma of the IL- 6 transgenic mice strongly suggests a central site of action of the cytokine and argues against a direct systemic effect of IL- 6 on the pituitary or adrenal gland. A central site for the effect of IL- 6 is further supported by the failure of LPS or IL- $1 \beta$ to produce fever in IL-6 deficient mice, which can be overcome by intracerebroventricular injection of the cytokine (Chai et al., 1996). Acute in vitro expo- 


\begin{tabular}{|c|c|c|c|c|}
\hline \multirow{2}{*}{$\begin{array}{l}\text { IL-6 } \\
\text { transgenic } \\
\text { mice }\end{array}$} & \multicolumn{2}{|c|}{ AVP content ${ }^{a}(\mathrm{pg} / \mu \mathrm{g}$ protein $)$} & \multicolumn{2}{|c|}{ CRF content $^{a}(\mathrm{pg} / \mu \mathrm{g}$ protein $)$} \\
\hline & Hypothalamus & Amygdala & Hypothalamus & Amygdala \\
\hline$+/+$ & $0.040 \pm 0.018$ & $0.016 \pm 0.009$ & $0.129 \pm 0.035$ & $0.061 \pm 0.012$ \\
\hline$+/ \mathrm{Tg}$ & $0.030 \pm 0.010$ & $0.019 \pm 0.006$ & $0.105 \pm 0.025$ & $0.043 \pm 0.013$ \\
\hline $\mathrm{Tg} / \mathrm{Tg}$ & $0.045 \pm 0.018$ & $0.024 \pm 0.009$ & $0.046 \pm 0.009$ & ND \\
\hline
\end{tabular}

$\overline{{ }^{a}}$ The AVP and CRF contents were determined as described in Materials and Methods; $n=10$ mice/group; ND, not determined.

\begin{tabular}{|c|c|c|}
\hline \multirow{2}{*}{$\begin{array}{l}\text { IL-6 } \\
\text { transgenic } \\
\text { mice }\end{array}$} & \multicolumn{2}{|c|}{ AVP/actin } \\
\hline & Average & SEM \\
\hline$+1+$ & 0.45 & 0.11 \\
\hline$+/ \mathrm{Tg}$ & 0.54 & 0.08 \\
\hline $\mathrm{Tg} / \mathrm{Tg}$ & 1.19 & 0.46 \\
\hline
\end{tabular}

Poly $\left(\mathrm{A}^{+}\right)$RNA from cerebrum (brain less cerebellum and olfactory bulb) was used for Northern blot analysis as described in Materials and Methods; $n=3$ mice per group.

Table 3. Adrenal corticosterone and pituitary AVP content in GFAP-IL6 transgenic mice ${ }^{1}$

\begin{tabular}{lll}
$\begin{array}{l}\text { IL-6 transgenic mice } \\
\text { 5 min restraint-stressed) }\end{array}$ & $\begin{array}{l}\text { Adrenal corti- } \\
\text { costerone content }^{a} \\
(\mathrm{ng} / \mathrm{mg} \text { protein })\end{array}$ & $\begin{array}{l}\text { Pituitary AVP } \\
\text { content }^{a} \\
(\mathrm{pg} / \mu \mathrm{g} \text { protein })\end{array}$ \\
\hline$+/+$ & $0.54 \pm 0.13$ & $0.059 \pm 0.019$ \\
$+/ \mathrm{Tg}$ & $1.34 \pm 0.28^{*}$ & $0.093 \pm 0.015$ \\
\hline
\end{tabular}

${ }^{a}$ The adrenal corticosterone and pituitary AVP contents were determined as described in Materials and Methods; $n=10$ mice/group for pituitary AVP;

${ }^{*} p<0.01$ versus $+/+$.

sure of the rat hypothalamus to IL- 6 stimulates hypothalamic factors, including CRF (Lyson et al., 1991; Navarra et al., 1991; Lyson and McCann, 1992; Spinedi et al., 1992; Yasin et al., 1994). Conflicting reports exist concerning the effect of IL-6 on AVP release from the rat hypothalamus (Loxley et al., 1991, 1993; Spinedi et al., 1992; Raber et al., 1994). However, the IL-6induced ACTH response was significantly suppressed by intracerebroventricular injection of antibodies against either CRF or AVP into the third ventricle (Kageyama et al., 1995).

In general, activation of the HPA axis is characterized by stimulation of CRF neurons, which can coproduce AVP, in the PVN of the hypothalamus and by secretion of these ACTH secretagogues from secretory terminals in the external zone of the median eminence. This, in turn, stimulates ACTH release from the anterior pituitary and subsequently causes the secretion of adrenal steroids. A single exposure to LPS, IL-1, brain surgery, or electric footshocks increases the AVP stores in terminals of CRF neurons in the external zone of the median eminence (Schmidt et al., 1995, 1996). During chronic or repeated stress, there is a shift from non-AVP-producing to AVP-producing CRF neurons, an increase in AVP vesicles in the median eminence (De Goeij et al., 1992a,b,c; Bartanusz et al., 1993), and release of AVP but not of CRF (Plotsky and Sawchenko, 1987; De Goeij et al., 1992a; Aguilera, 1994). This is consistent with the proposed role for AVP in maintaining the activity of the HPA axis after repeated stimulation (Hashimoto et al., 1988; Hauger et al., 1988; Scaccianoce et al., 1991; Lightman, 1994). The increased plasma

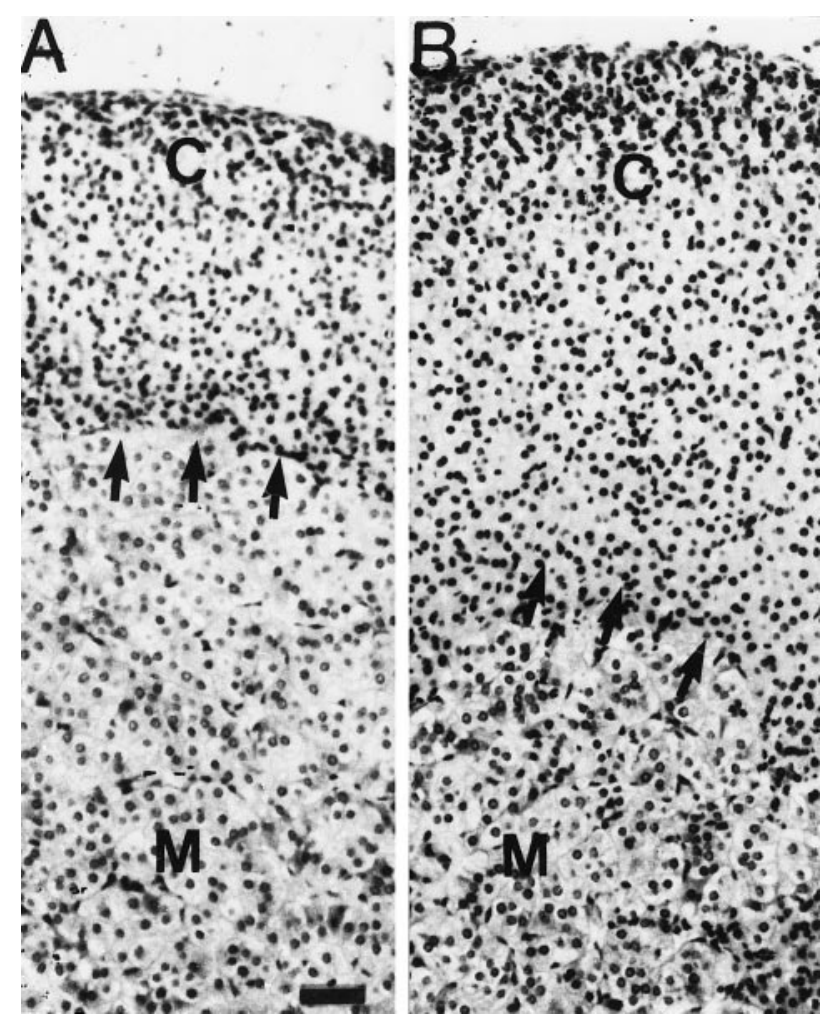

Figure 3. Histological appearance of the adrenal glands from wild-type $(+/+)(A)$ mice and heterozygous $(+/ T g)(B)$ IL-6 transgenic mice. The adrenal histology was determined as described in Materials and Methods. Arrows indicate the corticomedullary junction. Note that the cortex of the IL-6 transgenic mouse specimen is approximately double the thickness of the cortex of the wild-type control specimen and that there are both an increased number of cells (in the glomerulosa layer) and a hypertrophic response with nuclei spaced farther apart (in the layers reticularis and fasciculata). $C$, Cortex; $M$, medulla. Scale bar, $25 \mathrm{~m}$.

AVP levels in the stressed IL-6 transgenic mice suggest a pivotal role for AVP in modulating the HPA axis after acute immobilization stress but do not exclude a role for CRF after other stressors in this model.

The finding of increased plasma AVP levels in the IL-6 transgenic mice suggests that IL-6 activates the magnocellular AVP neurons, which directly secrete AVP into the general circulation through the vasculature of the posterior pituitary. The elevated stress-induced plasma AVP levels in the IL-6 transgenic mice may contribute to the hyperplasia of the adrenal gland. Intraperitoneal administration of vasopressin induces neural modulation of changes in catecholamines in the pigeon adrenal medulla (Mahata and Ghosh, 1991) and increases plasma corticosterone in addition to basal and ACTH-stimulated corticosterone secretory activity of zona fasciculata cells (Mazzocchi et al., 1995). A role 


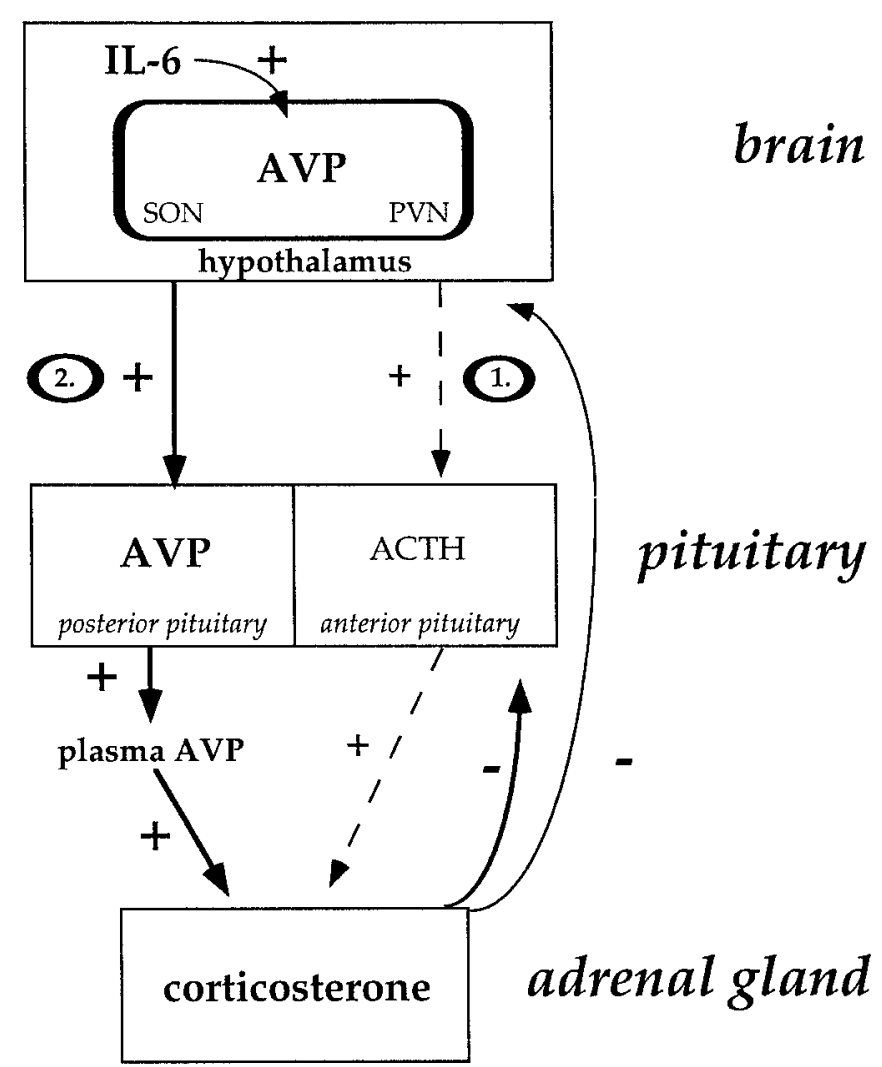

Figure 4. Diagram of proposed HPA axis modulation in IL-6 transgenic mice. This study demonstrates that chronic expression of IL-6 in the CNS can elevate plasma corticosterone with a smaller increase in the ACTH response compared with the controls, similar to the reported blunting of ACTH but not cortisol responses under pathophysiological conditions of high brain levels of IL-6 observed in humans. The increase in plasma AVP in the IL-6 transgenic mice may reflect activation of the magnocellular AVP neurons by IL-6 in this model (2). The adrenal gland could be directly activated by AVP or sensitized to ACTH (1).

for direct activation of AVP at the level of the adrenal gland is supported by the reported stimulation by AVP of inositol phosphates in adrenal medullary cultures (Bunn et al., 1990) and by increases in cytosolic free calcium (Larcher et al., 1992a). In addition, vasotocin (AVT), the amphibian counterpart of AVP produced by adrenochromaffin cells, stimulates corticosterone secretion in vitro from frog adrenocortical cells (Larcher et al., 1992b), which are homologous to the glomerulosa layer of the mammalian adrenal cortex (Delarue et al., 1981). Interestingly, the IL-6 transgenic mice exhibit hypertrophy in the glomerulosa layer (Fig. 3), and prolonged AVP administration was shown to stimulate this layer in the rat by promoting both hypertrophy and hyperplasia of the parenchymal cells (Payet and Lehoux, 1980; Payet et al., 1984; Lesniewska et al., 1991), whereas AVP antagonists depress the growth and secretory capacity of this layer (Mazzochi et al., 1995).

The elevated plasma corticosterone levels in the IL-6 transgenic mice were achieved with a smaller increase in the ACTH response compared with the controls. Downregulation of pituitary CRF (Tizabi and Aguilera, 1992) and AVP receptors (Aguilera, 1994) might be involved in desensitization of the pituitary ACTH response. The inhibitory effect of chronic osmotic stimulation on ACTH secretion despite high circulating levels of AVP has been proposed to result from a diminished activity of parvi- cellular PVN neurons and downregulation of pituitary AVP receptors (Aguilera, 1994). This downregulation of the pituitary CRF and AVP receptors might be caused either by prolonged stimulation of ACTH secretagogues or by an altered sensitivity to glucocorticoid feedback inhibition.

Modulation of the HPA axis in mice centrally expressing IL-6 could contribute to the pathology found in these mice (Campbell et al., 1993; Chiang et al., 1994; Heyser et al., 1997). Glucocorticoids can induce neuropathological alterations (Landfield, 1987; DeLeon et al., 1988; Sapolsky, 1992; Starkman et al., 1992; for review, see Sapolsky, 1996), which might involve the effect of corticosterone on brain-derived neurotrophic factor (Segal et al., 1995; Smith et al., 1995) and interaction with various transcription factors (Auphan et al., 1995; Scheinman et al., 1995; Wilckens, 1995). IL-1 may also contribute to the modulation of the HPA, because there is concurrent IL- $1 \alpha / \beta$ mRNA expression with the transgenic IL-6 expression (Chiang et al., 1994).

In summary, we found that transgenic expression of IL-6 in the CNS modulates the HPA axis. These findings support a role for IL-6 in interactions between the immune system and the nervous system not only at the peripheral (Straub et al., 1995) but also at the central level. Increased corticosterone levels in stressed IL-6 transgenic mice are associated with increased adrenal corticosterone content and plasma AVP levels and are paralleled by hyperplasia of the adrenal cortex and medulla. The decreased ACTH response together with the adrenal hyperplasia in the IL- 6 transgenic mice suggests direct activation at the level of the adrenal gland, which may be directly activated by AVP or sensitized by ACTH (Fig. 4). The exact mechanism of the HPA axis modulation by AVP remains to be determined, but these data support an important role for AVP in acute immobilization stress under conditions of chronically elevated brain levels of IL-6.

\section{REFERENCES}

Aguilera G (1994) Regulation of pituitary ACTH secretion during chronic stress. Front Neuroendocrinol 15:321-350.

Akwa Y, Schumacher M, Jung-Testas I, Baulieu EE (1993) Neurosteroids in rat schiatic nerves and Schwann cells. CR Acad Sci (III) (Paris) 316:410-414.

Amado JA, Lopez-Espadas F, Vazquez-Barquero A, Salas E, Riancho JA, Lopez-Cordovilla JJ, Garcia-Unzueta MT (1995) Blood levels of circulating cytokines in brain-dead patients: relationship with circulating hormones and acute-phase reactants. Metab Clin Exp 44:812-816.

Auphan M, DiDonato JA, Rosette C, Helmberg A, Karin M (1995) Immunosuppression by glucocorticoids: inhibition of NF- $\kappa \mathrm{B}$ activity through induction of I- $\kappa$ B synthesis. Science 270:286-290.

Badley JE, Bishop GA, St John T, Frelinger JA (1988) A simple, rapid method for the purification of poly A ${ }^{+}$RNA. Biotechniques 6:114-116.

Bartanusz V, Jezova D, Bertini LT, Tilders FJH, Aubry JM, Kiss JZ (1993) Stress-induced increase in vasopressin and corticotropinreleasing factor expression in hypophysiotrophic paraventricular neurons. Endocrinology 132:895-902.

Bateman A, Singh A, Kral T, Solomon S (1989) The immune hypothalamic-pituitary-adrenal axis. Endocr Rev 10:92-112.

Bauer J (1994) Alzheimer dementia: more than amyloid plaques and neurofibrillary degeneration. Fortschr Med 112:81-84.

Biglino A, Limone P, Forno B, Pollono A, Cariti G, Molinatti GM, Gionnini P (1995) Altered adrenocorticotropin and cortisol response to corticotropin-releasing hormone in HIV-1 infection. Eur J Endocrinol 133:173-179.

Brett FM, Mizisin AP, Powell HC, Campbell IL (1995) Evolution of neuropathologic abnormalities associated with blood-brain barrier breakdown in transgenic mice expressing interleukin-6 in astrocytes. J Neuropathol Exp Neurol 54:766-775.

Bunn SJ, Marley PD, Livett BG (1990) Receptor stimulated formation of inositol phosphates in cultures of bovine adrenal medullary cells: the effects of bradykinin, bombesin and neurotensin. Neuropeptides 15:187-194. 
Campbell IL, Abraham CR, Masliah E, Kemper P, Inglis JD, Oldstone MBA, Mucke L (1993) Neurologic disease induced in transgenic mice by cerebral overexpression of interleukin 6. Proc Natl Acad Sci USA 90:10061-10065.

Campbell IL, Hobbs MV, Kemper P, Oldstone MB (1994) Cerebral expression of multiple cytokine genes in mice with lymphocytic choriomeningitis. J Immunol 152:716-723.

Chai Z, Gatti S, Toniatti C, Poli V, Bartfai T (1996) Interleukin (IL)-6 gene expression in the central nervous system is necessary for fever response to lipopolysaccharide or IL-1- $\beta$ : a study on IL-6 deficient mice. J Exp Med 183:311-316.

Chiang CS, Stalder A, Samini A, Campbell IL (1994) Reactive gliosis as a consequence of interleukin-6 expression in the brain: studies in transgenic mice. Dev Neurosci 16:212-221.

De Goeij DCE, Binnekade R, Tilders FJH (1992a) Chronic stress enhances vasopressin but not corticotropin-releasing factor secretion during hypoglycemia. Am J Physiol 263:E394-E399.

De Goeij DCE, Dijkstra H, Tilders FJH (1992b) Chronic psychosocial stress enhances vasopressin but not corticotropin-releasing factor, in the external zone of the median eminence of male rats: relationship to subordinate status. Endocrinology 131:847-853.

De Goeij DCE, Jezova D, Tilders FJH (1992c) Repeated stress enhances vasopressin in corticotropin-releasing factor neurons in the paraventricular nucleus. Brain Res 577:165-168.

De Kloet ER, Oitzl MS, Schobiz B (1994) Cytokines and the brain corticosteroid receptor balance: relevance to pathophysiology of neuroendocrine-immune communication. Psychoneuroendocrinology 19:121-134.

Delarue C, Perroteau I, Leboulenger F, Netchitailo P, Leroux P, Jegou S, Belanger A, Tonon MC, Vaudry H (1981) In vitro effect of prostaglandins on corticosterone and aldosterone production by frog interrhenal gland. Biochem Biophys Res Commun 100:769-777.

DeLeon M, McRae T, Tsai JR (1988) Abnormal cortisol response in Alzheimer's disease linked to hippocampal atrophy. Lancet ii:391-392.

Elenkov IJ, Kovacs K, Kiss J, Bertok L, Vizi ES (1992) Lipopolysaccharide is able to bypass corticotrophin-releasing factor in affecting plasma $\mathrm{ACTH}$ and corticosterone levels: evidence from rats with lesions of the paraventricular nucleus. J Endocrinol 133:231-236.

Fassbender K, Rossol S, Kammer T, Daffertshofer M, Wirth S, Dollman M, Hennerici M (1994) Proinflammatory cytokines in serum of patients with acute cerebral ischemia: kinetics of secretion and relation to the extent of brain damage and outcome of disease. J Neurol Sci 122:135-139.

Frei K, Malipiero UV, Leist TP, Zinkernagel RM, Schwab ME, Fontana A (1989) On the cellular source and function of interleukin 6 produced in the central nervous system in viral diseases. Eur J Immunol 19:689-694.

Gadient RA, Otten U (1994) Identification of interleukin-6 (IL-6)expressing neurons in cerebellum and hippocampus of normal adult rats. Neurosci Lett 182:243-246.

Gadient RA, Otten U (1995) Interleukin-6 and interleukin-6 receptor mRNA expression in rat central nervous system. Ann NY Acad Sci 762:403-406.

Ganguli R, Brar JS, Chengappa KN, Yang ZW, Nimgaonkar VL, Rabin BS (1993) Autoimmunity in schizophrenia: a review of recent findings. Ann Med 25:489-496.

Gitter BD, Cox LM, Rydel RE, May PC (1995) Amyloid $\beta$ peptide potentiates cytokine secretion by interleukin- $1 \beta$-activated human astrocytoma cells. Proc Natl Acad Sci USA 92:10738-10741.

Gold PW, Licinio J, Wong ML, Chrousos GP (1995) Corticotropin releasing hormone in the pathophysiology of melancholic and atypical depression and in the mechanism of action of antidepressant drugs. Ann NY Acad Sci 771:716-729.

Gonzalez-Hernandez JA, Bornstein SR, Ehrhart-Bornstein M, SpathSchwalbe E, Jirikowsky G, Scherbaum WA (1994) Interleukin-6 messenger ribonucleic acid expression in human adrenal gland in vivo: new clue to a paracrine or autocrine regulation of adrenal function. J Clin Endocrinol Metab 79:1492-1497.

Harbuz MS, Stephanou A, Sarlis N, Lightman SL (1992) The effects of recombinant human interleukin (IL)- $1 \alpha$, IL- $1 \beta$ or IL- 6 on hypothalamo-pituitary-adrenal axis activation. J Endocrinol 133:349-355.

Hashimoto K, Suemaru S, Takao T, Sugawara M, Makino S, Fensuka O (1988) Corticotropin-releasing hormone and pituitary-adrenocortical responses in chronically stressed rats. Regul Pept 23:117-126.

Hatzinger M, Z’Brun A, Hemmeter U, Seifritz E, Baumann F, Holsboer-
Trachsler E, Heuser IJ (1995) Hypothalamic-pituitary-adrenal system in patients with Alzheimer's disease. Neurobiol Aging 16:205-209.

Hauger RL, Millar MA, Lorang M, Harwood JP, Agauilera G (1988) Corticotropin-releasing factor receptors and pituitary adrenal responses during immobilization stress. Endocrinology 123:396-405.

Heyser C, Masliah E, Samimi A, Campbell IL, Gold LH (1997) Progressive decline in avoidance learning paralleled by inflammatory neurodegeneration in transgenic mice expressing interleukin 6 in the brain. Proc Natl Acad Sci USA 94:1500-1505.

Hu Y, Dietrich H, Herold M, Heinrich PC, Wick G (1993) Disturbed immuno-endocrine communication via the hypothalamo-pituitaryadrenal axis in autoimmune disease. Int Arch Allergy Immunol 102:232-241.

Huell M, Strauss S, Volk B, Berger M, Bauer J (1995) Interleukin-6 is present in early stages of plaque formation and is restricted to the brains of Alzheimer's disease patients. Acta Neuropathol (Berl) 89:544-551.

Kageyama K, Watanobe H, Takebe K (1995) In vivo evidence that arginine vasopressin is involved in the adrenocorticotropin response induced by interleukin- 6 but not by tumor necrosis factor- $\alpha$ in the rat. Neuroimmunomodulation 2:137-140.

Landfield PW (1987) Modulation of brain aging correlates by long-term alterations of adrenal steroids and neurally active peptides. Prog Brain Res 72:279-300.

Larcher A, Lamacz M, Vaydry H (1992a) Effect of vasotocin on cytosolic free calcium concentrations in frog adrenocortical cells in primary culture. Endocrinology 131:1087-1093.

Larcher A, Delarue C, Idres S, Vaudry H (1992b) Interactions between vasotocin and other corticotrophic factors on the adrenal gland. J Steroid Biochem Mol Biol 41:795-798.

Lesniewska B, Nowak M, Miskowiak M, Nussdorfer GG, Malendowicz LK (1991) Effects of arginine-vasopressin on the pituitaryadrenocortical axis of intact and dexamethasone-suppressed rats. Exp Pathol 43:181-188.

Lightman SL (1994) How does the hypothalamus respond to stress? Semin Neurosci 6:215-219.

Loxley HD, Flower RJ, Buckingham JC (1991) Differential effects of dexamethasone and lipocortin 1 on the secretion of arginine vasopres$\sin (\mathrm{AVP})$ but not of corticotrophin releasing factor-41 (CRF-41) by the rat hypothalamus in vitro. Fundam Clin Pharmacol 5:412.

Loxley HD, Cowell AM, Flower RJ, Buckingham JC (1993) Effects of lipocortin 1 and dexamethasone on the secretion of corticotropinreleasing factors in the rat: in vitro and in vivo studies. J Neuroendocrinol 5:51-61.

Lyson K, McCann SM (1992) Involvement of arachidonic acid cascade pathways in interleukin-6 stimulated corticotropin-releasing factor release in vitro. Neuroendocrinology 55:708-713.

Lyson K, Milenkovic L, McCann SM (1991) The stimulatory effect of interleukin- 6 on corticotropin-releasing hormone and thyrotropin releasing hormone in vitro. Prog Neuroendocr Immunol 4:161-165.

Maes M, Scharpe S, Meltzer HY, Bosmans E, Suy E, Calabrese J, Cosyns P (1993) Relationships between interleukin-6 activity, acute phase proteins, and function of the hypothalamic-pituitary-adrenal axis in severe depression. Psychiatry Res 49:1979-1992.

Maes M, Bosmans E, Meltzer HY (1995) Immunoendocrine aspects of major depression. Relationships between plasma interleukin-6 and soluble interleukin-2 receptor: prolactin and cortisol. Eur Arch Psychiatr Clin Neurosci 245:172-178.

Mahata SK, Ghosh A (1991) Neural modulation of lysine vasopressininduced changes of catecholamines in the adrenal medulla of the pigeon. Neuropeptides 18:29-33.

Mastorakos G, Chrousos GP, Weber JS (1993) Recombinant interleukin-6 activates the hypothalamic-pituitary-adrenal axis in humans. J Clin Endocrinol Metab 77:1690-1694.

Mastorakos G, Weber JS, Magiakou MA, Gunn H, Chrousos GP (1994) Hypothalamic-pituitary-adrenal axis activation and stimulation of systemic vasopressin secretion by recombinant interleukin-6 in humans: potential implications for the syndrome of inappropriate vasopressin secretion. J Clin Endocrinol Metab 79:934-939.

Matsuzono Y, Narita M, Akutsu Y, Togashi T (1995) Interleukin-6 in cerebrospinal fluid of patients with central nervous system infections. Acta Paediatr 84:879-883.

Mazzocchi G, Malendowicz LK, Meneghelli V, Gottardo G, Nusdorfer GG (1995) In vitro and in vivo studies of the effects of arginine vaso- 
pressin on the secretion and growth of rat adrenal cortex. Histol Histopathol 10:359-370.

Mellon SH, Nussbaum S, Hochberg RB (1980) Biosynthesis of lipidal derivative of pregnenolone and hydroepiandrosterone by the adrenal. J Biol Chem 255:5566-5572.

Muramami N, Fukata J, Tsukada T, Kobayashi H, Ebisui O, Segawa H, Muro S, Imura H, Nakao K (1993) Bacterial lipopolysaccharideinduced expression of interleukin- 6 messenger ribonucleic acid in the rat hypothalamus, pituitary, adrenal gland, and spleen. Endocrinology 133:2574-2578.

Navarra P, Tsagarakis S, Faria MS, Rees LH, Besser GM, Grossman AB (1991) Interleukins-1 and -6 stimulate the release of corticotropinreleasing hormone-41 from rat hypothalamus in vitro via the eicosanoid cyclooxygenase pathway. Endocrinology 128:37-44.

Payet N, Lehoux JG (1980) A comparative study of the role of vasopressin and $\mathrm{ACTH}$ in the regulation of growth and function of rat adrenal glands. J Steroid Biochem 12:461-467.

Payet N, Deziel Y, Lehoux JG (1984) Vasopressin: a potent growth factor in adrenal glomerulosa cells in culture. J Steroid Biochem 20:449-454.

Perez L, Alvarez-Cermeno JC, Rodriguez C, Roldan E, Brieva JA (1995) B cells capable of spontaneous IgG secretion in cerebrospinal fluid from patients with multiple sclerosis: dependency on local IL-6 production. Clin Exp Immunol 101:449-452.

Plotsky PM, Sawchenko PE (1987) Hypophysial-portal plasma levels, median eminence content, and immunohistochemical staining of corticotropin-releasing factor, arginine vasopressin, and oxytocin after pharmacological adrenalectomy. Endocrinology 120:1361-1369.

Raber J, Merlo Pich E, Koob GF, Bloom FE (1994) IL-1 $\beta$ potentiates the acetylcholine-induced release of vasopressin from the hypothalamus in vitro, but not from the amygdala. Neuroendocrinology 59:208-217.

Raber J, Koob GF, Bloom FE (1995) Interleukin-2 (IL-2) induces corticotropin-releasing factor (CRF) from the amygdala and involves a nitric oxide-mediated signaling: comparison with the hypothalamic response. J Pharmacol Exp Ther 272:815-824.

Raber J, Mehta PP, Kreifeldt M, Parsons LH, Weis F, Bloom FE, Wilson MC (1997) Coloboma hyperactive mutant mice exhibit regional and transmitter-specific deficits in neurotransmission. J Neurochem 68:176186.

Sapolsky RM (1992) Stress, the aging brain, and the mechanisms of neuron death. Cambridge, MA: MIT.

Sapolsky RM (1996) Stress, glucocorticoids, and damage to the nervous system: the current state of confusion. Stress 1:1-19.

Sarlis NJ, Stephanou A, Knight RA, Lightman SL, Chowdrey HS (1993) Effects of glucocorticoids and chronic inflammatory stress upon anterior pituitary interleukin-6 mRNA expression in the rat. $\mathrm{Br} \mathrm{J}$ Rheumatol 32:653-657.

Scaccianoce S, Muscolo LAA, Gigliana G, Navarra D, Nicolai R, Angelucci L (1991) Evidence for a specific role of vasopressin in sustaining pituitary-adrenocortical stress response in the rat. Endocrinology 128:3138-3143.

Scheinman RI, Cogswell PC, Lofquist AK, Baldwin Jr AS (1995) Role of transcriptional activation of $\mathrm{I}-\kappa \mathrm{Ba}$ in mediation of immunosuppression by glucocorticoids. Science 270:283-286.

Schmidt ED, Janszen AW, Wouterlood FG, Tilders FJ (1995) Interleukin-1 induced long-lasting changes in hypothalamic corticotropin-releasing hormone $(\mathrm{CRH})$ neurons and hyperresponsiveness of the hypothalamuspituitary-adrenal axis. J Neurosci 15:7417-7426.

Schmidt ED, Binnekade R, Janszen AW, Tilders FJ (1996) Short stressor induced long-lasting increases of vasopressin stores in hypothalamic corticotropin-releasing hormone $(\mathrm{CRH})$ neurons in adult rats. J Neuroendocrinol 8:703-712.

Schöbitz B, de Kloet ER, Sutanto W, Holsboer F (1993) Cellular localization of interleukin $6 \mathrm{mRNA}$ and interleukin 6 receptor mRNA. Eur J Neurosci 5:1426-1435.

Segal RA, Pomeroy SL, Stiles CD (1995) Axonal growth and fasculation linked to differential expression of BDNF and NT3 receptors in developing cerebellar tranular cells. J Neurosci 15:4970-4981.

Shimada K, Koh CS, Yanagisawa N (1993) Detection of interleukin-6 in serum and cerebrospinal fluid of patients with neuroimmunological diseases. Arerugi 42:934-940.

Skowsky W, Rosembloom AA, Fisher DA (1974) Radioimmunoassay of arginine vasopressin in serum: development and application. J Clin Endocrinol Metab 38:278-287.

Slotnick BM, Leonard CM (1975) A stereotaxic atlas of the albino mouse forebrain. Rockville, MD: US Department of Health, Education, and Welfare.

Smith MA, Makino S, Kvetnansky R, Post RM (1995) Stress and glucocorticoids affect the expression of brain-derived neurotrophic factor and neurotrophin-3 mRNAs in the hippocampus. J Neurosci 15:1768-1777.

Spangelo BL, Judd AM, MacLeod RM, Goodman DW, Isakson PC (1990) Endotoxin-induced release of interleukin-6 from rat medial basal hypothalami. Endocrinology 127:1779-1785.

Spangelo BL, deHoll PD, Kalabay L, Bod BR, Arnaud P (1994) Neurointermediate pituitary lobe cells synthesize and release interleukin-6 in vitro: effects of lipopolysaccharide and interleukin- $1 \beta$. Endocrinology 135:556-563.

Spath-Schwalbe E, Born J, Schrezenmeier H, Bornstein SR, Stromeyer P, Drechsler S, Fehm HL, Porzsolt F (1994) Interleukin-6 stimulates the hypothalamus-pituitary-adrenocortical axis in man. J Clin Endocrinol Metab 79:1212-1214.

Spinedi E, Hadid R, Daneva T, Gaillard RC (1992) Cytokines stimulate the $\mathrm{CRH}$ but not the vasopressin neuronal system: evidence for a median eminence site of interleukin-6 action. Neuroendocrinology $56: 46-53$.

Starkman MN, Gebarski SS, Berent S, Schteingart DE (1992) Hippocampal formation volume, memory dysfunction, and cortisol levels in patients with Cushing's syndrome. Biol Psychiatry 32:756-765.

Stephanou A, Sarlis NJ, Knight RA, Lightman SL, Chowdrey HS (1992) Effects of cyclosporine A on the hypothalamic-pituitary-adrenal axis and anterior pituitary interleukin-6 mRNA expression during chronic inflammatory stress in the rat. J Neuroimmunol 41:215-222.

Straub RH, Lang B, Falk W, Scholmerich J, Singer EA (1995) In vitro superfusion method for the investigation of nerve-immune cell interaction in murine spleen. J Neuroimmunol 61:53-60.

Taga T, Kishimoto T (1992) Interleukin-6. In: Human cytokines, handbook for basic and clinical research (Aggarwal BB, Gutterman JU, eds), pp 143-167. Oxford: Blackwell Scientific.

Tizabi Y, Aguilera G (1992) Desensitization of the hypothalamic-pituitary-adrenal axis following prolonged administration of corticotropinreleasing hormone or vasopressin. Neuroendocrinology 56:611-618.

Vankelecom H, Carmeliet P, Van Damme J, Billiau A, Denef C (1989) Production of interleukin-6 by folliculo-stellate cells of the anterior pituitary gland in a histiotypic cell aggregate culture system. Neuroendocrinology 49:102-106.

Weitzman R, Glatz TH, Fisher DA (1978) The effect of hemorrhage and hypertonic saline upon plasma oxytocin and arginine vasopressin in conscious dogs. Endocrinology 103:2154.

Wilckens T (1995) Glucocorticoids and immune function: physiological relevance and pathogenetic potential of hormone dysfunction. Trends Pharmacol Sci 16:193-197.

Yasin SA, Costa A, Forsling ML, Grossman A (1994) Interleukin-1 $\beta$ and interleukin-6 stimulate neurohypophysial hormone release in vitro. J Neuroendocrinol 6:179-184.

Yeung MC, Pulliam L, Lau AS (1995) The HIV envelope protein gp120 is toxic to human brain-cell cultures through the induction of interleukin-6 and tumor necrosis factor- $\alpha$. AIDS 9:137-143.

Zhou D, Kusnecov AW, Shurin MR, DePaoli M, Rabin BS (1993) Exposure to physical and psychological stressors elevates plasma interleukin 6: relationship to the activation of hypothalamic-pituitaryadrenal axis. Endocrinology 133:2523-2530. 